\title{
EVALUATION OF THE STRUCTURE OF THE NATIONAL UNION OF CIVIL ENGINEERING CONSTRUCTION, FURNITURE AND WOODWORKERS, NIGERIA AND ITS CONTRIBUTIONS TO THE PROGRESSIVE RELATIONSHIPS AMONG THE STAKEHOLDERS
}

\author{
AYANTUNJI, Oyelekan (PhD) \\ Department of Human Resources Development, Osun State University, Okuku Campus, Osun State, Nigeria \\ DOI: 10.36108/ljerhrm/8102.01.0172
}

\begin{abstract}
This paper discussed the structure of the National Union of Civil Engineering Construction, furniture and woodworkers, Nigeria and its contributions to the existence of a harmonious and progressive relationship among the stakeholders in the union since 1994 when it was formed. The union is a merger of two formerly independent industrial unions from the restructuring of the unions in Nigeria in 1978. The paper identified the contribution of structure as key in the attainment of peace and progressive among the stakeholders in the union and recommends the use of appropriate structure in the running of the affairs of an organization since it has the potentials of contributing to peace and progress in the organization.
\end{abstract}

Key words:Harmony, Peace, Progress, Strategy, Structure, Trade Unions.

\section{Background}

There are three major actors, most especially, in a typical British system of Industrial Relations. These are:

i) the workers and their trade unions;

ii) the Employers and their associations; and

iii) the government and its agencies.

The role of the workers is to supply the skills that are necessary for the production of goods and services in an organization while the role of the workers unions is to ensure adequate remuneration for the workers, supply of their skills for the production of the goods and the services. The role of the employers is to supply the materials for the production of the goods and services of the organization while the role of the employers' associations or unions is to ensure adequate return on investment for the employers for their supply of the materials for the production of the goods and services of the organization. The role of the government is to create an enabling environment for the production of the goods and services in the organization while the role of their agents is to ensure adequate compliance to rules and regulations for the production of the goods and services of the organization.

\section{Definition of a Trade Union}

According to the Nigeria Trade Union Act (1990), a trade union may be defined as "any combination of workers or employers, whether temporary or permanent the purpose of which is to regulate the conditions of employment of the workers. From this definition it is evident that it is both the workers and the employers that can form trade unions. Secondly, it is evident that the objectives of a trade union are the regulation of the conditions of employment of the workers. Thirdly, it is incumbent that for any organization or combination to be qualified as a trade union its object must be the regulation of the condition of employment of workers (Scharf, 2018). Flippo's (1976) and Klitgaard \& Norgaard (2014) definition of a trade union throw more light, most especially on what constitute the "condition of employment of workers" and what the term "regulate" means, most especially in the context of what may be called a trade union. According to Flippo (1976) a trade union may be defined as "an organization that is formed to promote, to protect, and to improve the social, the political and the economic interests of its members. From this definition it becomes clear that the term "conditions of employment of workers" means "the social, the political and the economic interests of workers while the term "regulate" means to "promote, to protect and to improve" the social, the political and the economic interests of workers (Klitgaaard \& Norgaard, 2014). Salamon's (2000) definition of a trade union further throw some other dimensions to the understanding of what a trade union is, namely, that a trade union's functions are not limited to the workplace interest of its members only but also to the interests of their members outside the workplace in the society. Salamon (2000) definition of a trade union is "an organisation which consists of employees which seeks to organise and represent its members both in the workplace and in society. 


\section{Methods of Trade Unions}

It is obvious that the objectives of a trade union are known through the various definitions of a trade union examined so far. What is significant that is yet to be known is or are the method(s) that trade unions use to achieve the stated objectives. Chen, Chen \& Liao (2011) and Flanders (1975) identified three of these methods, namely:

i. the industrial methods;

ii. the political methods; and

iii. the social and educated methods.

Yesufu (1984) emphasised most especially the social and the educational methods. Mentioned as part of educational methods, according to Yesufu (op cit) and Flauders (1976) are various trainings, seminars and conferences attended by trade unions which sharpen their skills in performing their functions. The various mutual benefit organizations such as cooperatives which trade unions organize are good examples of social benefit activities of trade unions (Scharf, 2018). Under industrial methods, Flauders (1976) gives such examples as consultations, negotiations, arbitrations, strikes, among others while under political methods are activities such as lobbying, pressure groupings and such other political activities that relate to party political activities.

\section{The Structure of the Trade Unions in Nigeria}

In the study conducted by Bird, Short and Toffel (2017) argue that irrespective of ideological bending,governments accommodate structural pressure as well as short-term electoral interests to keep the economy on track and implement austerity measures in labour market policy that, in effect, reduce union resources and capacity to mobilise.Available records point to the fact that the first trade union in Nigeria was formed in 1912 although evidences abound also that prior to 1912 there had been evidences of trade union activities in Nigeria such as a proposed strike of the workers of the works department in 1894 as claimed in Tokuboh (1985); and Omole (1991).

The structure of the trade union investment during this period was not specific. While some trade unions adopted the craft structure some other unions adopted the house or the regional structure. Some even adopted a general structure.

From 1978, however, after the restructuring of the trade unions in Nigeria into seventy Industrial unions all the unions in the country adopted a three-tier structure, namely, the National, the state and the local structures (see figure 1).

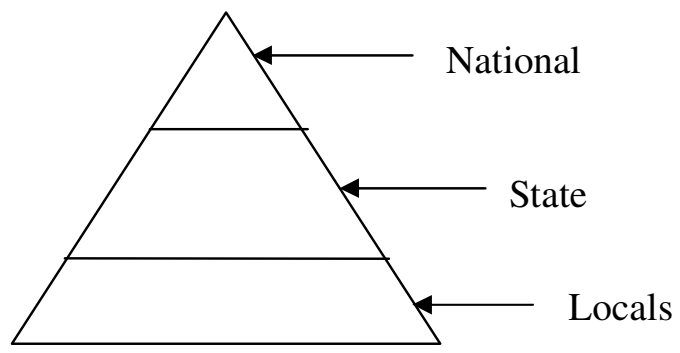

\section{Figure 1: The Structure of Trade Unions in Nigeria}

From this figure it will be clear that a typical trade union (Industrial Union) in Nigeria adopts a three-tier structure, namely: the National, the state and the locals. At the National and the state levels are three major organs through which the unions administer their members. These are, at the National level:

i) the National Delegates Conference;

ii) the National Executive Committees; and;

iii) the Central Working committee.

There may be other organs of administration in some unions which are not typical of other unions. For instance, the National union of Civil Engineering construction, furniture and woodworkers has an organ called the unit. Some of the organizations that constitute the membership of the union have such organs for the administration and convenience of their members in the larger union. The National union of Banks, Insurance and Finance 
Institutions Employees also has a similar organ called Domestics, and another are called area committees. These are merely for the convenience of the groups of organizations within the larger union that constitute such organs.

At the state level of all the Industrial Unions in Nigeria are the following major organs:

i) the states delegate conferences;

ii) the States Executive Committees; and

iii) the states working committees.

The roles of these organs are very similar, save that the roles of the organs at the National level cover the whole of each respective union while the state organs cover each of the states of each union where it has members.

The role of the respective delegate conferences is to formulate rules, regulations and policies for each union at their respective areas of operations while the role of the executive committees is to ensure compliance to the rules, regulations and policies of the respective delegate conferences in their respective areas of operations (Frege, Heery \& Turner, 2014). While the respective delegate conferences hold quadrennially; the executive committees hold annually. The role of the working committees at each of the levels in the structure of the unions is to run the affairs of the unions at their respective areas of operation on daily basis, complying with the rules, regulations and policies of their respective delegate conferences and executive committees. It should be instructive to emphasise that the rules, regulations, policies and other activities of each union at the state level must never be at variance with the rules, regulations, policies and other activities of the union at the national level.

At the grassroot or shopfloor level in the structure of each of the industrial unions in Nigeria since 1978 are local officers elected among the rank and file members of each union at the grassroot or shopfloor. It is also of importance to note that both the state and the national levels in the structure of each industrial union in Nigeria especially since 1978 have the benefit of the services of appointed professional trade union administrators to guide the activities of each union at these two levels. It is only at the grassroot level that this opportunity does not exist.

\section{The Importance of Structure in an Organization}

Bird et al (2017) and Waterman Jr, et. al (1988) identify seven major elements that influences the success or failure of an organization. These are: the structure, the system, the style of leadership/administration of the organization, the staff in the organization, the skills of the staff in the organization, the strategies to achieve the objectives of the organization and the super ordinate objectives of the organization. Among all these, structure is identified as key. Quoting Mullins (1999) and Chen et al. (2011) the structure of an organization affects not only productivity and economic efficiency but also the bargaining power, corporate bond, morale and job satisfaction of the workplace. Therefore, getting the structure right is the first step in an organization for every labour unions (Chen et al., 2011).

\section{Organizational Structures}

Going through literature such as Scharf (2018), Bird et al. (2017), Klitgaard \& Norgaard (2014) and Chen et al. (2011), there are many types of organization structures, notable among which are:
i) simple structures;
ii) machine bureaucratic structures;
iii) the professional bureaucratic structures;
iv) the divisionalised structures;
v) the missionary structures; and
vi) the adhoc structures.

\section{The Simple Structure}

The name tells it all. The structure is very simple not much more than one large union consisting of one or a few top managers-one of who dominates by the pull to centralize, a group of operators who do the basic work (Bird et al., 2017). Little of the behaviour in the organization is formalized and minimal use is made of planning, training or the liaison devices. The absence of standardization means that the structure is organic and has little need for staff analysts. Likewise, there are few middle line managers because so much of the coordination is handled at the top. The organization must be flexible because it operates in a dynamic environment which must be simple, as 
must the production system. The organization is often young, in part because time drives it toward bureaucracy, in part because the vulnerability of simple structures causes many of them to fail. Simple structures are often small organizations because size can drive it towards bureaucracy.

\section{The Machine BureaucracyStructure}

As stated by Mintzberg (1988), the machine bureaucracy is the offspring of the Industrial Revolution "when jobs became highly specialized and work because highly standardized. As opposed to the simple structure the machine bureaucracy elaborates its administration". According to Mintzberg (1988) the machine bureaucracy requires a large technostructure to design and maintain its systems of standardization, notably those that formalize its behaviours and plan its actions. By virtue of the organization's dependence on these systems, Mintzberg (1988) says, the technostructure gains a good deal of informal power, resulting in a limited amount of horizontal decentralization, reflecting the pull towards standardization.

\section{The Professional BureaucracyStructure}

According to Frege, Heery \& Turner (2014) the difference between the professional bureaucracy and the machine bureaucracy is that while the machine bureaucracy relies on the standardization of the work processes or outputs for its coordination the professional bureaucracy relies on the standardization of skills through training for its coordination. As stated again by Mintzberg, the pull to professionalise dominates in a professional bureaucratic structure. Professional bureaucracy is called for whenever an organization finds itself in an environment that is stable yet complex. Complexity requires decentralization to highly trained individuals and stability enables them to apply standardized skills and so to work with a good deal of autonomy. To ensure that autonomy, the production system must be highly regulating, complex nor automated.

\section{The Divisionalised Structure}

The divisionalised structure is not so much of an integrated organization as a set of rather independent entities coupled together by a loose administrative structure (Scharpf, 2018). Compared to the professional bureaucratic structure, whereas those entities of the professional bureaucracy are individuals, in the divisionalised structure the entities are units in the middle line generally called "divisions", exerting a dominant pull to balkanise. The divisionalised structure is different from the other structures because it is not a complete structure but a partial one super imposed on others. Each division has its own structure. The divisionalised structure is controlled through direct supervision. So as not to interfere with the necessary divisional autonomy required the headquarters of the divisionalised structure relies on performance control systems, otherwise called "standardization of outputs". To design these control systems headquarters create a small technostructure across from the small central support staff that headquarters set up to provide certain services common to the divisions such as legal counsel and public relations.

\section{The Adhoc Structure}

The adhoc organizational structure also called the matrix structure is the structure suitable for most of the hightechnology organizations of the modern days such as the aerospace, petrochemical and think tank consulting organizations of the modern societies (Chen et al., 2011). The bureaucratic structures are too inflexible and the simple structure too autocratic. Most modern day organizations require "project structures", that is, structures that can fuse experts drawn from different specialties into smoothly functioning creative teams. Adhocracy is an organic structure that relies for coordination on mutual adjustment among its highly trained and highly specialised experts, which it encourages by the extensive use of the liaison devices - integrating managers, standing committees, and task forces. Typically, the experts are grouped in functional units for housekeeping purposes but deployed in small market based project teams to do their work. To these teams, located all over the structure in accordance with the decisions to be made, is delegated power over different kinds of decisions. So, the structure becomes decentralized selectively in the vertical and horizontal dimensions, that is, power is distributed unevenly, all over the structure, according to expertise and need.

\section{The Missionary Structure}

In the word of Klitgaard and Norgaard (2014) when an organization is dominated by the pull to evangelise its member are encouraged to pull together and there tends to be a loose division of labour, little job specialization and a reduction of the various forms of differentiation found in the other structures such as the strategic apex from the rest of staff from line or administration from operations, between operators, between divisions and so on. What holds the missionary together, that is, provides for its coordination, is the standardization of norms, the sharing of values and beliefs among all its members and the key to ensuring this is the socialization of their 
members effected through the design parameter of indoctrination. Mintzberg (1988) assert that once the new member has been indoctrinated into the organisation, once he or she identifies strongly with the common beliefs, then he or she can be given considerable freedom to make decisions. "Thus", Mintzberg (1988) continued, "the result of effective indoctrination is the most complete form of decentralization, and because other forms of coordination need not be relied upon, the missionary formalises little of its behaviour and as such makes minimal use of planning and control systems.

\section{An Evaluation of the Structure of the National Union of Civil Engineering Construction, Furniture and Woodworkers in Nigeria}

The National Union of Civil Engineering Construction, Furniture and Woodworkers, is one of the current twentynine Industrial Unions in Nigeria. It has a membership of about fifty thousand spread across the country. Before the current economic stress in the country the union had membership close to one hundred thousand. The union is one of the biggest in the country, whether public or private sector union. Over the years the union enjoys tremendous peace with only one incidence of national strike in 2014 over agitation for improvement in condition of service. Apart from this nationwide strike that lasted for only one week, there have not been significant strike that cuts across the union or last more than one day. On occasions that such localized strikes occur they are not recorded in the books of the union because they are considered insignificant.

The National Union of Civil Engineering Construction, Furniture and Woodworkers, Nigeria has the structure of a typical Industrial Union in Nigeria as discussed earlier with three levels in the structure of its administration National, State and Local; and three major organs of administration at the National and the state levels. The local level at the grassroot where members are, are run by elected officers among the rank and file members. When policies are formulated at the National level they are implemented at the appropriate levels according to the dictate of the policies. Policies formulated at either the state or local levels must not be at variance with the policies formulated at the National. So also, policies formulated at the local levels must never be at variance with the policies formulated at the state and national levels.

\section{Indices of Evaluation of a Structure}

Rumelt (1988) identifies four major indices by which a business strategy may be evaluated which are applicable in the evaluation of a structure too. These indices are:

i) consistency;

ii) consonance;

iii) feasibility; and

iv) advantage.

According to Rumelt (1988) a business policy, including a structure must be enduring, that is, lasts and practiced for a reasonable period of time of about two to ten years minimum and up to twenty-five years maximum giving room for change in relation to the environment. According to him a policy or strategy including a structure should be consistent with the environment where it is to be operated. For instance, in Nigeria the governance structure is generally three-tier for big corporations, both public and private if such cooperations have membership at the grassroot. Apart from consistency and consonance, Rumelt (1988) emphasise the need for a policy, strategy and a structure also to be feasible. If a policy, strategy or structure is not practicable (feasible) or workable it then is of no value to the organisation using it. Similarly, Rumelt (1988) emphasise the need for a business policy, strategy and indeed a structure too, to be advantageous to the organisation operating it, otherwise, of what value will a policy or strategy and indeed a structure be, if it will not be of advantage to the operators.

\section{Conclusion}

This paper discussed the structure of the National Union of Civil Engineering Construction, Furniture and Woodworkers and reviewed the activities of the union most especially since 1996 when it came into existence in Nigeria.The union is an amalgamation of two previously independent industrial unions from the restructuring of the industrial unions in Nigeria in 1978.The paper identified a harmonious and progress relationship among the stakeholders in the union since its formation in 1996 and concludes that perhaps, among other things, the structure of the union, could have contributed immensely to the achievements of the union including the harmonious and progressive relationships enjoyed over the years since 1994. This confirms the assertion in literature that, among the factors that contribute to the success of an organisation, a good structure is key. This conclusion, perhaps, suggests that organizations should seek appropriate structure that are consistent, in consonance with the 
environments where they will be operated, feasible and can lead to advantage so that the organizations will be able to achieve its objectives, both long and short terms.

\section{References}

Bird,Y.Z; Short, J.I \& Toffel, M.W.(2017). Organisation structures and the improvement of working conditions in global supply chains: Legalisation, participation and economic incentives. Harvard Business School Working Paper, No 18 -003

Chen, T; Chen, Y. \& Liao, H. (2011). Labour unions, bargaining power and corporate bond yield spreads: Structural credit model perspectives. Journal f Banking \& Finance, 35, 2084 - 2098

Federal Government of Nigeria. 1990. Trade union act.

Flauders, A. (1975). Management and unions: The Theories and Reforms of Industrial Relations. London: Faber and Faber.

Flippo, E. B. (1976). Principles of personal management. New York: McGraw-Hill

Frege, C.A; Heery, E. \& Turner, L.I.(2014). Comparative coalition building and the revitalization of the labour movement. In IRRA $5^{\text {th }}$ Annual Proceedings on Union Revitalisation in Comparative Perspective, $122-$ 130.

Klitgaard, M.B. \& Norgaard, A.S.(2014). Structural stress or deliberate decision? Government partisanship and the disempowerment unions in Denmark. European Journal of Political Research, 53, $404-421$.

Mintzberg, H. (1988). The structuring of organisations. In J. B. Quinn, Henry Mintzberg and R. M. James. The Strategy Process: Concepts, Contexts and Cases.New Jersey: Prentice-Hall New Jersey.

Mullins, L. J. 1999. Management and organisation behaviour $\left(5^{\text {th }}\right.$ Ed). New York: Prentice-Hall.

National Union of Civil Engineering Construction Furniture and Woodworks, handbook for members.Nigeria Constitution(199).

Omole, L. (1991). Origin and development of union education in industrial relations services. Ibadan: Sege Publishers

Rumelt, R. (1988). The evaluation of business strategy. In J. B. Quinn, H. Mintzberg and R. M. James (ed.). The Strategy Process: Concepts, Contexts and Cases. New Jersey: Prentice-Hall.

Salamon, M. (2000). Industrial relations theory and practice. New York: Prentice-Hall.

Scharpf, F.W. (2018). Games real actors play: Actor-centred institutionalism in policy research. New York: Routledge

Tokuboh, M. A. (1985). Labour movement in Nigeria: Past and present.Lagos: Lantern Publications.

Waterman Jr., R. H; Peters, T. J. \& Philips J. R. (1988). The 7s framework. In J. B. Quinn, H. Mintzberg and James R. M. (ed.).The Strategy Process: Concepts, contexts and cases. New Jersey: Prentice-Hall,

Yesufu, T. M. (1984). The dynamics of industrial relations: The Nigerian experience. Ibadan: University Press Limited 